\title{
Learning needs of adult patients surgery
}

\section{Yetişkin cerrahi hastalarının öğrenim gereksinimleri}

\author{
Meryem YILMAZ
}

Cumhuriyet Üniversitesi Sağlık Bilimler Fakültesi, Hemșirelik Bölümü, Sivas

Corresponding author: Meryem YILMAZ, Cumhuriyet Üniversitesi Sağlık Bilimler Fakültesi, Hemşirelik Bölümü, Sivas

E-mail: yilmazmm01@hotmail.com

Received/Accepted: April 21,2016/January 11, 2017

Conflict of interest: There is not a conflict of interest.

\begin{abstract}
SUMMARY
Objective: The purpose of the study was to identify the learning needs of adult surgical patients. Method: The study design used was cross-sectional and descriptive. Four hundred and twenty three adult surgical patients were included. Data, questionnaire and The Patient Learning Needs Scale- (PLNS), Turkish version, were used. The scores were then statistically analyzed using the mean, standard deviation, independent sample t test, ANOVA and Mann-Whitney U test. Results: The average age of patients was 47.69. The mean total score of PLNS is $180.15(36.95)$ and the highest level of significance is of treatment and complications sub-dimension with 3.96. Marital status, type of surgery and the information provided at discharge, on the PNLS total score, were statistically significant.

Conclusions: According to the results this study, the information provided is insufficient associated with discharge for surgical patients and is patients request more information. Ensuring that surgical patients' informational needs have been met prior to hospital discharge will contributes for successful self-management of at home and increase the recovery and the prevention of complications and rehospitalization after discharge.
\end{abstract}

Keywords: Patient discharge, surgery, learning needs, nursing

\section{ÖZET}

Amaç: Bu çalışmanın amacı yetişkin cerrahi hastalarının öğrenim gereksinimlerini belirlemekti.

Yöntem: Çalışma kesitsel ve tanımlayıcı olarak yapıldı. Çalışmaya 423 yetişkin cerrahi hastası katıldı. Veriler anket sorusu ve hasta öğrenim gereksinimleri ölçeğinin Türkçe versiyonu kullanılarak toplandı. Puanların istatistiksel analizinde ortalama, standart sapma, t-test, ANOVA ve Mann-Whitney U testi ile hesaplandi.

Bulgular: Hastaların yaş ortalaması 47.69 idi. Öğrenim gereksinimleri toplam puan ortalamas1 $180.15(\mathrm{SD}=36.95)$ ve ölçeğin tedavi ve komplikasyonlar alt boyutunun önemlilik düzeyi 3.96 ile en yüksek olarak belirlendi. Evlilik durumu, cerrahinin tipi ve taburculuk sırasında verilen bilgi taburculuk öğrenim gereksinimleri ölçeğinin toplam puanı arasında istatistiksel olarak fark anlamliydi $(\mathrm{P}<0.05)$.

Sonuç: Bu çalışmanın sonuçlarına göre cerrahi hastalarına taburculuk ile ilişkili verilen bilginin yetersiz olduğu ve hastaların daha fazla bilgiye gereksinim duydukları belirlendi. Cerrahi hastalarının taburculuk öncesi bilgi gereksinimlerinin sağlanması evde kandi bakımlarını başarmalarına komplikasyonların, taburculuk sonrası yeniden hastaneye yatışlarını önlenmesine ve iyileşmelerine katkı verecektir.

Anahtar Sözcükler: hasta taburculuğu, cerrahi, öğrenim gereksinimleri 


\section{INTRODUCTION}

Surgical patients usually being discharged before completing recovery. Therefore, after hospital discharge the patient must assume responsibility for care. This has led to an increase in the home care needs of surgical patients. Evidence shows that discharge planning (DP) is an essential process, prior to hospital discharge, for successful self-management of recovery at home among surgical patients.1,2 Patients is need information after surgery. Thus it is important identifying which learning needs are important to the patient 3 and the appropriate learning content should be planned for each patient with the help of this knowledge. Therefore discharge process begins with an assessment of the patient's requirements. The evaluation of the surgical patient's needs, discharge is very important for ensure optimal recovery and prevention of complications especially during the early days. The American Nurses' Association (ANA) defines DP as the part of the continuity of care process which is designed to prepare the patient for the next phase of care and to assist in making any necessary arrangements for that phase of care.4 DP, is an interdisciplinary team responsible and focusing on improving outcomes, 5 the physician is legally responsible for the patient at hospital discharge; however, the nurse provides coordination of the planning 1,6. According to Caroll and Dowling7 DP, is an accepted nursing intervention aimed at the prevention of complications after hospital discharge. Bull and Roberts8 described four stages for proper hospital discharge; determination of the patient's discharge needs, development of the DP, implementation of the DP (patient education and recommendations for services) and evaluation of the DP. Foust9 indicated that determining a patients' postdischarge needs is the first, and complex, step of the DP. Discharge needs are complicated by the uncertainty and variability of patient recovery, understanding of discharge directions and the unseen home environment. However, focus on acute care areas has traditionally been emphasized with many general medical checks rather than focusing on patient need4. In the past, DP preferences of the patient have not been included in DP activities; prior focus has been on activities determined by the medical staff. 10

Hospitals in Turkey have not made a strong effort to provide adequate and effective DP. For most institutions discharge from the hospital is often associated with insufficient information provided, rather than being a planned process that includes patient input and preferences. It is important to determine the patient's priorities in anticipation of post-discharge learning needs using appropriate measurements. In Turkey, studies of discharge planning among surgical patients and their learning needs, using the PNLS, have been carried out.1117 The focus of this study was to determine the learning needs for discharging among surgical patients, with the aim of developing DP according to patient priorities so that they could manage their care at home.

\section{MATERIAL and METHODS}

\section{Study Design/Sample/Setting}

The purpose of the study was to identify the learning needs of adult surgical patients. This study was designed as a descriptive and cross-sectional survey. Data was collected in Sivas, in the Central Anatolia Region of Turkey. The study was conducted at a 600-bed surgical ward (including: general surgery, urology, orthopedics and cardiovascular surgery) during 2013. The Central Anatolia Region has a structure that is representative for Turkey in general. It is one of the seven regions of Turkey. At this institution where the survey was conducted, discharge education was not previously planned. The health professionals would provide short verbal information about discharge in a few hours and discuss issues such as pain control.

The selection criteria of patients who were; could read and write in Turkish, 17 years of age or older, had no difficulty in communicating, an inpatient stay for at least three days following surgery, and voluntarily participation.

\section{Instruments}

\section{The Questionnaire}

Data was obtained from the "Questionnaire" and "The Patient Learning Needs Scale -Turkish version- (PLNS-T)". This scale includes 5 point Likert type items and consisted of 50 items.

The questionnaire was developed for this study and included the following sections: age, education, marital status, employment status, household type of residence, living with people, social assurance, type of surgery, information on issues to be considered at home after discharge, type of information, person giving information, and the status of satisfaction with the information. 


\section{The Patient Learning Needs Scale -Turkish version- (PLNS-T)}

The PLNS is designed to measure the general learning needs of adult patients that have medical or surgical illness. Bubela and colleagues3 originally developed "The Patient Learning Needs Scale (PLNS) to identify the information needs of patients at discharge, in 1990. The scale consists of 50 items and 7 subscales. The subscales and total scores are evaluated and the scores ranged from 50250. There is no cut-off point for the scale. Increase in total and subscale scores is important for individual needs. Likert-type scaling methods include: " $1=$ not important," " $2=$ a little important," " $3=$ what is very important and not," " $4=$ very important," " $5=$ extremely important;" results are scored between 1 and 5 in the form assessed. The Turkish version of the scale's validity and reliability studies were conducted by Catal and Dicle.18 The Turkish version of the scale was found to have internal consistency, with a reliability coefficient of 0.93 and cronbach alpfa of 0.95 .

\section{Data collection}

Data was collected between February and May of 2014. Data was collected by face-to-face interviews by the researcher in patient rooms. The process took approximately 20 to 25 minutes for completion of the data collection.

The Ethics Committee of the University gave approval for the study prior to data collection. Permission was obtained, in writing, from the Surgical Departments for the implementation of this study. When the researcher conducted the questionnaire survey, each participant was informed of the purpose, content, method, and duration of the research and verbal consent was received. All of the questionnaires were anonymous, and all personal data were confidential. All participants volunteered for the study.

\section{Statistical analysis}

The data were analyzed using the Statistical Package for Social Sciences (SPSS Inc., Chicago, IL, USA), for Windows 16.0; descriptive statistics were used for socio-demographic characteristics and to compare descriptive characteristics and the status of receiving discharge information after surgery according to the PLNS-T. The scores were then analyzed using the mean, standard deviation, independent sample $t$ test, ANOVA and MannWhitney U test. 


\section{RESULTS}

Table 1. Comparison of the total scores on PLNS according to participants' demographic characteristics $(\mathrm{N}=423)$

\begin{tabular}{|c|c|c|c|c|c|}
\hline Characteristic & $\mathbf{n}$ & $\%$ & PLNS Mean (SD) & Test & p-value \\
\hline Age & & & $47.69(1.70)$ & & \\
\hline Length of hospital stay (days) & & & $12.33(1.19)$ & & \\
\hline \multicolumn{6}{|l|}{ Gender } \\
\hline Male & 188 & 44.4 & $179.36(36.96)$ & $\mathrm{t}=.494$ & .622 \\
\hline Female & 235 & 55.6 & $181.14(37.01)$ & & \\
\hline \multicolumn{6}{|l|}{ Marital status } \\
\hline Married & 324 & 76.6 & $183.36(36.31)$ & $\mathrm{t}=-2.866$ & .004 \\
\hline Single & 99 & 23.4 & $165.86(40.26)$ & & \\
\hline \multicolumn{6}{|l|}{ Education } \\
\hline Literate & 71 & 16.8 & $188.35(34.16)$ & & \\
\hline Primary education & 216 & 51.1 & $180.49(35.77)$ & $\mathrm{F}=2.584$ & .053 \\
\hline High school education & 96 & 22.7 & $172.56(38.55)$ & & \\
\hline University education & 40 & 9.5 & $182.00(41.67)$ & & \\
\hline \multicolumn{6}{|l|}{ Employment status } \\
\hline Employed & 129 & 30.5 & $178.91(36.93)$ & $\mathrm{t}=4.56$ & .649 \\
\hline Unemployed & 294 & 69.5 & $180.69(37.00)$ & & \\
\hline \multicolumn{6}{|l|}{ Health Insurance } \\
\hline Yes & 407 & 96.2 & $179.71(36.95)$ & $Z=-1.147$ & .252 \\
\hline No & 16 & 3.8 & $191.38(36.14)$ & & \\
\hline \multicolumn{6}{|l|}{ Type of surgery } \\
\hline Urgent & 63 & 14.9 & $166.51(33.46)$ & $\mathrm{t}=-3.212$ & .001 \\
\hline Elective & 360 & 81.4 & $182.54(37.06)$ & & \\
\hline \multicolumn{6}{|l|}{ Caregiver in home } \\
\hline Present & 18 & 4.3 & 179.99(37.31) & & \\
\hline Absent & 405 & 95.7 & $183.83(28.12)$ & $Z=-630$ & .529 \\
\hline
\end{tabular}

Participants' demographic characteristics are presented in Table 1 as the mean and standard deviation or frequencies and percentages. The study included 423 adult surgical patients; 235 male and 188 female. The patients ranged from 17 to 85 years of age with a mean age of $47.69(\mathrm{SD}=$ 1.70). Among the patients, $55.7 \%$ were male, $69.5 \%$ were married, $47.3 \%$ were educated through primary school, and $72.4 \%$ had elective surgery,
$69.5 \%$ were unemployed, $59.6 \%$ were living in an apartment with central heating, $95.7 \%$ were living with someone at home, and $97.2 \%$ had insurance. The length of hospital stay (days) averaged 12.33 $(\mathrm{SD}=1.19)$. Table 1 shows the statistically significant difference between being married and type of surgery with the average total score on the PNLS $(\mathrm{p}<0.05)$.

Table 2. Comparison of the total scores on PLNS according to receiving discharge information

\begin{tabular}{|c|c|c|c|c|c|}
\hline $\begin{array}{l}\text { Features associated with receiving } \\
\text { information }\end{array}$ & $\mathbf{n}$ & $\%$ & $\begin{array}{c}\text { PLNS total scores } \\
\text { Mean (SD) } \\
\end{array}$ & Test & p-value \\
\hline \multicolumn{6}{|c|}{ Receiving information about post-discharge( $\mathrm{N}=423)$} \\
\hline Yes & 267 & 63.1 & $173.46(33.34)$ & $\mathrm{t}=5.006$ & .000 \\
\hline No & 156 & 36.9 & $191.60(40.00)$ & & \\
\hline \multicolumn{6}{|l|}{ Person who information( $n=267)$} \\
\hline Physician & 96 & 35.9 & $173.15(33.62)$ & & \\
\hline Nurse & 71 & 26.6 & $184.87(31.50)$ & $\mathrm{F}=4.864$ & .003 \\
\hline Physician and Nurse & 100 & 37.5 & $165.82(32.47)$ & & \\
\hline \multicolumn{6}{|c|}{ Satisfaction information provided $(\mathrm{N}=423)$} \\
\hline Yes & 161 & 38.1 & $166.61(30.62)$ & $\mathrm{t}=6.160$ & .000 \\
\hline No & 262 & 61.9 & $188.47(38.08)$ & & \\
\hline
\end{tabular}


In study, $63.1 \%$ of patients received the information about need to be careful at home was determined, $26.6 \%$ of these patients received information from nurses and 38.1\% were satisfied with the knowledge. The information given to patients at discharge included: $36.9 \%$ were told not to lift something heavy, $37.8 \%$ had wound care discussed, $27.0 \%$ were taught how to recognize complications, $14.2 \%$ received information on possible complications, $16.5 \%$ were taught how to prevent complications, $28.1 \%$ were advised on which situations should bring them back to the hospital, $22.7 \%$ received information on safe activities, $40.0 \%$ had pain management discussed, $40.5 \%$ learned about time to control pain, 39.7\% learned about bath or shower time, $11.8 \%$ had sexual activity discussed, and $31.9 \%$ learned about the recommended duration of rest (Table 2).

Table 3. Comparison of the total scores on PLNS according to the information given at discharge to patients

\begin{tabular}{|c|c|c|c|c|c|}
\hline Information about topics & $\mathbf{n}$ & $\%$ & Mean(SD) & t-test & $\begin{array}{c}p- \\
\text { value }\end{array}$ \\
\hline \multicolumn{6}{|l|}{ Not removing heavy things } \\
\hline Yes & 156 & 36.9 & 171.87(33.59) & 3.574 & .000 \\
\hline No & 267 & 63.1 & 184.99(38.01) & & \\
\hline \multicolumn{6}{|l|}{ Wound care } \\
\hline Yes & 160 & 37.8 & 175.74(33.60) & 1.920 & .056 \\
\hline No & 263 & 62.2 & $182.83(38.66)$ & & \\
\hline \multicolumn{6}{|c|}{ How to recognize complications } \\
\hline Yes & 114 & 27.0 & $175.72(32.83)$ & 1.501 & .134 \\
\hline No & 309 & 73.0 & 181.79(38.26) & & \\
\hline \multicolumn{6}{|l|}{ Which activities can safely } \\
\hline Yes & 96 & 22.7 & 179.16(35.96) & .300 & .764 \\
\hline No & 327 & 77.3 & $180.44(37.28)$ & & \\
\hline \multicolumn{6}{|l|}{ Pain management } \\
\hline Yes & 169 & 40.0 & 169.67(32.75) & 4.887 & .000 \\
\hline No & 254 & 60.0 & 187.13(37.98) & & \\
\hline \multicolumn{6}{|l|}{ When control of the future } \\
\hline Yes & 172 & 40.5 & $174.07(33.58)$ & 2.749 & .006 \\
\hline No & 251 & 59.5 & 184.04(38.48) & & \\
\hline \multicolumn{6}{|l|}{ Making bath or shower } \\
\hline Yes & 168 & 39.7 & 169.70(33.44) & 4.848 & .000 \\
\hline No & 255 & 60.3 & 187.04(37.59) & & \\
\hline \multicolumn{6}{|l|}{ Rest duration } \\
\hline Yes & 135 & 31.9 & 172.81(31.77) & 2.819 & .005 \\
\hline No & 288 & 68.1 & $183.59(38.72)$ & & \\
\hline \multicolumn{6}{|l|}{ Time to start sexual activity } \\
\hline Yes & 50 & 11.8 & $179.12(33.11)$ & .210 & .834 \\
\hline No & 373 & 88.2 & $180.29(37.47)$ & & \\
\hline
\end{tabular}

Table 3 shows a comparison of the information given at discharge to patients after surgery, and the total mean scores on the PLNS. Statistically significant findings included: not moving heavy things, pain management, pain control, taking a bath or shower, and duration of rest $(\mathrm{p}<0.05)$; other study factors were not significant with an average total PNLS score ( $p>0.05)$. 
Table 4. Patients' subscales scores and severity of learning needs $(\mathrm{n}=423)$

\begin{tabular}{lccccc}
\hline Subscales & $\begin{array}{c}\text { Number of } \\
\text { items PLNS }\end{array}$ & $\begin{array}{c}\text { Scala } \\
\text { Min-Max }\end{array}$ & $\begin{array}{c}\text { Patient } \\
\text { Min-Max }\end{array}$ & Mean (SD) & Need severity \\
Treatment and complications & 9 & $9-45$ & $16-45$ & $35.61(5.46)$ & 3.96 \\
Medications & 8 & $8-40$ & $14-40$ & $31.41(5.76)$ & 3.92 \\
Quality of life & 8 & $8-40$ & $8-40$ & $29.98(6.69)$ & 3.75 \\
Life activities & 9 & $9-45$ & $9-45$ & $33.35(7.27)$ & 3.70 \\
Skin care & 5 & $5-25$ & $6-25$ & $17.43(4.76)$ & 3.49 \\
Community and the follow-up & 6 & $6-30$ & $6-30$ & $18.08(6.41)$ & 3.01 \\
Feelings related to condition & 5 & $5-25$ & $5-25$ & $14.29(6.04)$ & 2.86 \\
Total mean score & 50 & $50-250$ & $79-250$ & $180.15(36.95)$ & 3.60 \\
\hline
\end{tabular}

The Patient Learning Needs Scale had mean scores as shown in Table 4. The overall mean scale scores among patients were 180.15 $(\mathrm{SD}=36.95)$. The subscale mean scores included: medications $31.41 \quad(\mathrm{SD}=5.76)$, activities of daily life $33.35 \quad(\mathrm{SD}=7.27)$,

\section{DISCUSSION}

The results of this study showed that more than half of the patients did receive discharge information after their surgery, prior to leaving the hospital. But it was often delivered the day of discharge and was not planned or unsufficient with regard to the areas of information provided, such as pain control and rest duration. In addition, the present study found that even for the patients that were informed, by health care professionals, there continued to be higher learning needs post discharge. The reason for this result may be that patients were not give information tailored to their needs by the health care professionals. Therefore, based on this information, development of DPs individualized to patient needs, prior to leaving hospital, is required for recovery at home post discharge. Prior studies have also shown that patients did not receive adequate information or received incorrect information before discharge. ${ }^{14,19}$ Uzun and colleagues $^{15}$ found that before discharge, $50 \%$ of patients did not have sufficient information with regard to discharge. In the present study, participants had a PLNS average total score of 180.15 ( $\mathrm{SD}=36.95)$; therefore, the patient learning needs were significant according to the PNLS. The most important learning requirement for patients was found to be treatment and complications; the second most important was activities of daily living, on the subscales. In a study recently Yilmaz and Ozkan ${ }^{11}$ to describe learning needs of surgery patients found were information for medications and quality of life needed before discharge from the hospital. Another study was performed to determine learning needs of patients who has community and follow-up $18.08(\mathrm{SD}=6.41)$, feelings about the situation $14.29(\mathrm{SD}=6.04)$, treatment and complications $35.61(\mathrm{SD}=5.46)$, quality of life $29.98(\mathrm{SD}=6.69)$, and skin care $17.43(\mathrm{SD}=4.76)$.

abdominal surgery before discharge found the mean total score of PLNS is 207.52 \pm 24.14 and the highest level of significance is of drugs subdimension. ${ }^{12}$ Şendir et al. ${ }^{13}$ reported that the most important learning needs were about treatment and complications, activities of living, and enhancing quality of life who patients total hip and knee arthroplasty. In a study recently ${ }^{20}$, examined learning needs who have undergone coronary artery bypass graft $(\mathrm{CABG})$ surgery before hospital discharges found that ranked by patients as most important were chest and leg woundet care, medication information, other pertinent information and complications. In other a study examined patients' learning needs after colorectal cancer surgery raported that the most important information was about illness-related knowledge, improvements in the quality of life and surgical treatment and complications ${ }^{21}$. Prior recent studies in Turkey have not frequently made use of the PNLS. Those that had used this scale found that the mean total PNLS of patients was similar to the results of our study. ${ }^{14,16,17}$ In a study reported by Johansson et al. ${ }^{22}$ the most important learning needs were those associated with complications and symptoms, the second most important reported were the learning needs associated with medication and the third was information regarding activities of daily living.

The results of the present study showed that age, gender and educational status did not affect the patients' learning needs; however, marriage, type of surgery and information associated with discharge of patients were important factors. 
Table 5 Comparison of the total scores on PLNS according to clinical departments

\begin{tabular}{|c|c|c|c|c|c|c|c|c|}
\hline \multirow[b]{2}{*}{ Subscales } & \multicolumn{6}{|c|}{ Clinics } & \multirow[b]{2}{*}{$\begin{array}{c}\text { ANOVA } \\
(F)\end{array}$} & \multirow[b]{2}{*}{$\begin{array}{l}p- \\
\text { value }\end{array}$} \\
\hline & $\begin{array}{c}\text { Neurosurgery } \\
n=26 \\
\text { Mean(SD) }\end{array}$ & $\begin{array}{c}\text { Heart-vascular } \\
\text { surgery } \\
n=25 \\
\text { Mean(SD) }\end{array}$ & $\begin{array}{c}\text { General } \\
\text { surgery } \\
n=205 \\
\text { Mean(SD) }\end{array}$ & $\begin{array}{c}\text { Ortophedic } \\
n=74 \\
\text { Mean(SD) }\end{array}$ & $\begin{array}{c}\text { Urology } \\
n=75 \\
\text { Mean(SD) }\end{array}$ & $\begin{array}{c}\mathrm{KBB} \\
\mathrm{n}=18 \\
\text { Mean(SD) }\end{array}$ & & \\
\hline Treatment and complications & $38.58(3.73)$ & $35.72(4.50)$ & $36.15(5.41)$ & $35.51(6.03)$ & $34.01(4.53)$ & $31.94(7.30)$ & 5.075 & .000 \\
\hline Medications & $33.73(3.90)$ & $29.28(5.51)$ & $32.03(5.65)$ & $31.80(5.94)$ & $30.17(5.40)$ & $27.61(7.37)$ & 4.507 & .001 \\
\hline Quality of life & $31.65(5.37)$ & $31.28(4.71)$ & $31.19(6.56)$ & $30.35(7.10)$ & $26.80(5.55)$ & $23.67(7.75)$ & 9.314 & .000 \\
\hline Life activities & $36.15(5.04)$ & $35.20(5.42)$ & $34.43(6.98)$ & $34.11(7.05)$ & $30.59(5.82)$ & $22.78(10.00)$ & 13.764 & .000 \\
\hline Skin care & $19.62(4.24)$ & $16.64(4.34)$ & $17.55(4.84)$ & $19.46(4.34)$ & $14.73(3.95)$ & $16.94(4.65)$ & 9.697 & .000 \\
\hline $\begin{array}{l}\text { Community and the follow- } \\
\text { up }\end{array}$ & $22.08(4.05)$ & $17.44(6.04)$ & $17.95(6.62)$ & $20.70(6.52)$ & $15.80(4.95)$ & $13.44(5.42)$ & 9.143 & .000 \\
\hline Feelings related to condition & $16.46(5.60)$ & $14.32(4.52)$ & $14.66(6.36)$ & $16.07(6.15)$ & $11.79(4.34)$ & $10.06(5.74)$ & 6.892 & .000 \\
\hline Total & $198.27(26.99)$ & $179.88(26.93)$ & $183.96(37.38)$ & $188.00(39.40)$ & $163.89(27.04)$ & $146.44(43.16)$ & 9.041 & .000 \\
\hline
\end{tabular}

The mean Subscale scores and total mean PLNS scores according to surgical clinic are noted in Table 5. The patients in the neurosurgery clinic had higher learning needs 
These findings are consistent with the findings previously reported by Taşdemir et al. ${ }^{17}$ who examined the learning needs of neurosurgery patients. These results may be interpreted as a need for information among patients in all circumstances.Uzun et al. ${ }^{15}$ found that there was no statistically significant difference between the PLNS and the characteristics of patients excluding gender status (female), with regard to determining post discharge learning needs of general surgery patients. Demirkıran and Uzun ${ }^{14}$ similarly found a higher mean total PLNS score among female patients. Johansson and colleagues found demographic variables such as age, gender, education and working life were clearly related to learning needs after hip arthroplasty. Women tend to engage in self-care related activities more than men. Therefore, women patients view the need for information about illness and treatment to be of greater importance than males and generally receive more information than male patients ${ }^{23}$. But, Alkubati et al.$^{20}$ reported that, after CABG surgery patients who men, younger and middle-aged patients, highly educated and were working reported more information needs. Fredericks ${ }^{24}$ similarly found that after CABG patients men need more information than women and the relationships between learning needs and sociocultural characteristics (education, gender and age). In a study reported that age, gender and education were clearly related to learning needs. ${ }^{21}$ These results may be interpreted as a need for information among patients in all circumstances.

The findings of this study show that physicians provided most of the information given at patient discharge. In addition, the results showed a higher mean total PNLS among patients informed by nurses at discharge. This suggests that nurses should be more involved with discharge planning. In those patients that received information from both nurses and physicians, there were fewer learning needs compared to those who received information from only physicians or nurses. In the study reported by Demirkıran and Uzun ${ }^{14}$ patients that received discharge information both by physicians and nurses had fewer learning needs. In the study reported by Yilmaz and $\mathrm{Cifc}^{25}$ the home care needs were determined for patients after openheart surgery; nurses provided more information about discharge, but the information in general was insufficient, and this may have led to physical problems. Uzun et al. ${ }^{15}$ found that physicians supplied $43.3 \%$ of discharge information whereas nurses provided $15.6 \%$ of such information. In a study planned to define an informative approach to homecare, in patients receiving ear surgery, doctors were found to take a more active role in informing the patients than nurses. ${ }^{16}$ In a study reported by Behar-Horenstein et al. ${ }^{26}$, physicians were found to be the primary source of patient information, followed by nurses. Nurses were the primary source of information about treatments, medications and procedures. Therefore, nurses play a vital role in the DP process ${ }^{27}$ because they are involved in direct patient care activities, $24 \mathrm{~h}$ a day. ${ }^{4}$ It is the responsibility of the nurses to assess patients thoroughly, to evaluate their need for assistance, and to provide adequate information to patients and their families for post-discharge. Nurses are ideal discharge planners and coordinators of the DP process. Although not new to nursing, the findings of this study and others Pirani ${ }^{5}$ and Watts and Garner ${ }^{4}$ show that nurses are often more involved in routine activities such as physical care and many institutions continue to ignore their essential role as discharge planners. Individualized DP that includes appropriate and useful information for patients and their family caregivers is needed. However, Huber and Mclelland $^{10}$ identified a lack of congruence between patient and caregivers' preferences in DP. In this study the findings show a higher mean total score on the PNLS and its subscales, for patients hospitalized in the neurosurgical department, compared to other clinics. Similarly, in a study to determine the learning needs of neurosurgery patients, reported by Taşdemir et al. the total mean score on the PNLS was high. ${ }^{17}$ This might be explained by the importance of neurosurgical procedures with regard to future life. The second highest mean total PNLS score was among orthopedic patients; this might be explained by the technical procedures used and the need for patient explanation with regard to these procedures. In addition, the information provided helps with the patient returning to their activities of daily living, as soon as possible. In a study reported to evaluate the efficacy of comprehensive discharge planning, for patients with hip fractures, the findings showed that in the intervention group improved discharge planning shortened the length of hospital stay, increased self-care knowledge and quality of life. ${ }^{28}$

The findings of this study showed that currently the information given at discharge includes control of pain, medication timing as well as bathing; however, the amount of information received on all issues was rated as low and was not provided according to patient need. The learning needs of patients that had surgery was higher among the patients that received information before discharge, as shown on the higher mean total PLNS scores, the information provided was not adequate. In a 
previous study found the informational needs of surgical patients following discharge, based on the PLNS, was related to activity, wound care, complications, pain management, elimination, and personal care. In a study conducted by Pieper et al. $^{29}$ to examine incision care knowledge and discharge concerns of patients that had undergone gastric bypass bariatric surgery, knowledge of incision care and the amount of information received about incision care were rated as low. The five most frequently mentioned post discharge concerns included: bowel trouble at home, wound pain at home, looking for wound complications, watching for wound infection, and activity limitations. In a study reported by Pieper et al. ${ }^{30}$ conducted to examine wound care knowledge and concerns, prior to discharge from an acute care hospital, the greatest concern among patients was with regard to how active to be at home, wound pain, looking for wound complications, watching for wound infection, trouble with bowels, and treating wound pain at home. Similar results of the most frequent learning needs as wound care, complication information, and psychological factors has been reported by Subeh et al. ${ }^{31}$ Therefore, effective DP is a vital link in the continuity of care post discharge among surgical patients and should be provided by caregivers that have information based on the needs of patients, which depends on the individual health status and the type of care required at discharge. ${ }^{1}$ Patient preferences for information are one aspect of effective DP that is important for improve quality of care after surgery. It is the responsibility of nurses to assess patients thoroughly, to evaluate their learning needs and to provide effective individualized information to patients and their

\section{REFERENCES}

1. Ganzella M, Zago MMF. The hospital discharge as evaluated by patients and their caregivers: an integrative literature review. Acta Paul Enferm 2008; 21: 351-55.

2. McMurray A, Johnson P, Wallis M, Patterson E, Griffiths S. General surgical patients' perspectives of the adequacy and appropriateness of discharge planning to facilitate health decisionmaking at home. J Clin Nurs 2007; 16: 1602-9.

3. Bubela N. The patient learning needs scale: reliability and validite. J Adv Nurs 1990, 15: 1181-7. families for post discharge recovery from surgical procedures. Therefore, for nurses should be organized in-service training programs for incorporation of discharge planning activities into daily practica. In addition, introduce the PLNS as part of in-service training usable to determine surgical patients' post-discharge needs.

\section{CONCLUSION}

In this study, the learning needs of surgical patients were found to be high before hospital discharge. The current discharge information includes education about medication, activities of daily living, treatment and complications. However, a patient-centered systematic approach to hospital discharge is required to facilitate the transition from hospital to home so that patient health outcomes are improved. The results of this study can assist nurses clinically to better understand the discharge learning needs of surgical patients in acute care hospital wards. The results suggest that nurses must accurately identify the post-discharge learning needs of surgical patients to facilitate successful self-management of recovery at home. Thus, according to specific requirements they can achieve an individualized, patient-centered approach to DP to reduce the hospital length of stay and unplanned readmission to the hospital. To improve outcomes, research that examines issues including discharge learning needs of patients undergoing surgery is needed. In addition, the role of nursing should be emphasized and the factors leading to lack of DP identified. Further research is needed to identify patient learning needs and the professional interventions required to fulfill these needs.

4. Watts R, Gardner H. Nurses' perceptions of discharge planning. Nurs Health Sci 2005; 7: 175-83.

5. Pirani SSA. Prevention of delay in the patient discharge process. Journal For Nurses in Staff Development 2010; 26: E15.

6. Pieper B, Sieggreen $M$, Freeland B, Kulwicki P, Frattaroli M, Sidor D, Palleschi MT, Burns J, Bednarski D, Garretson B. Discharge information needs of patients after surgery. J Wound Ostomy Continence Nurs 2006; 33: 281-91.

7. Caroll A, Dowling M. Discharge planning: Communication, education and patient participation. B J Nursing 2007; 16: 882-6. 
8. Bull M, Robert J. Components of a proper hospital discharge for elders. J Adv Nurs 2001; 35: 571-81.

9. Foust JB. Discharge planning as part of daily nursing practice. Appl Nurs Res 2007; 20: 72-7.

10. Huber DL, McClelland E. Patient preferences and discharge planning transitions. J Prof Nurs 2003; 19: 204-10.

11. Yilmaz E, Özkan S. Learning needs of surgical patients. Anadolu Hemşirelik ve Sağlık Bilimleri Dergisi 2015; 18: 107-15.

12. Başaran Dursun H, Yilmaz E. Batın cerrahisi yapılan hastaların öğrenim gereksinimleri. Celal Bayar Üniversitesi Sağlık Bilimleri Enstitüsü Dergisi 2015; 2: 65-70.

13. Şendir $M$, Büyükyılmaz $F$, Muşovi D. Patients' discharge information needs after total hip and knee arthroplasty: a quasiqualitative pilot study. Rehabil Nurs 2013; 38: 264-71.

14. Demirkıran G, Uzun Ö. Koroner arter bypass greft ameliyatı geçiren hastaların taburculuk sonrası öğrenim gereksinimleri. Dokuz Eylül Üniversitesi Hemşirelik Yüksekokulu Dergisi 2012; 28: $1-12$.

15. Uzun O, Ucuzal M, Inan G. PostDischarge learning needs of general surgery patients. Pak J Med Sci, 2011; 27: 634-7.

16. Ugras GA, Öztekin D, Kanan N. Kulak ameliyatı geçiren hastaların evde bakım konusunda bilgilendirilme durumu. Anadolu Hemşirelik ve Sağlık Bilimleri Dergisi 2011; 14: 24-30.

17. Tasdemir N, Guloglu S, Turan Y, Cataltepe $\mathrm{T}$, Ozbayir T. Learning needs of neurosurgery patients. Journal of Neurological Sciences [Turkish] 2010; 27 : 25, 414-20.

18. Çatal E, Dicle A. Hasta öğrenim gereksinimleri ölçeği'nin Türkiye'de geçerlik ve güvenirlik çalışması, Dokuz Eylül Üniversitesi Hemşirelik Yüksekokulu Dergisi 2008;1: 19-32.

19. Henderson A, Zernike W. A study of the impact of discharge information for surgical patients. J Adv Nurs 2001;35: 1-7.

20. Alkubati SA, Al-Zaru IM, Khater W, Ammouri AA. Perceived learning needs of Yemen patients after coronary artery bypass graft surgery. J Clin Nurs 2013; 22: 930-8.

21. Castro-Peraza ME, Lorenzo-Rocha N, Johansson K, Garzon-Rodriguez E, Sosa-
Alvarez MI, Afonso-Martin R, PeresteloPerez L. Person-centered Education-I: Patients' learning needs after colorectal cancer surgery. The International Journal of Person Centered Medicine 2012; 2: 622-6.

22. Johansson K, Hupli M, Salantera S. Patients' learning needs after hip arthroplasty. J Clin Nurs 2002; 11: 634-9.

23. Suhonen R, Nenonen H, Laukka A, Valimaki M. Patients' informational needs and information received do not correspond in hospital. J Clin Nurs 2006; 14: 1167-76.

24. Fredericks S. The relationship between CABG patient characteristics and perceived learning needs: a secondary analysis. Can J Cardiovasc Nurs 2009; 19: 13-9.

25. Yilmaz M, Çifçi ES. Açık kalp ameliyatı geçirmiş bireylerin evde bakım gereksinimlerinin belirlenmesinde bir model: Fonksiyonel sağlık örüntüleri. Türk Göğüs Kalp Damar Cerrahisi Dergisi 2010; 18: 183-9.

26. Behar-Horenstein, L, Guin PK, Hurlock G, Leclear E, Philipose $\mathrm{M}_{2}$ Shellnut D, Ward M, \& Weldon J. Improving patient care through patient-family education programs. Hospital Topics 2005; 83: 21-7.

27. Graham G, Gallagher R, Bothe J. Nurses' discharge planning and risk assessment: behaviours, understanding and barriers. $\mathrm{J}$ Clin Nurs 2013; 22: 2338-46.

28. Lin PC, Wang CH, Chen CS, Liao LP, Kao $\mathrm{SF}, \mathrm{Wu} \mathrm{HF}_{\text {. }}$ To evaluate the effectiveness of a discharge-planning programme for hip fracture patients. J Clin Nurs 2009; 18 : 1632-9.

29. Pieper B, Sieggreen M, Nordstrom CK, Kulwicki P, Freeland B, Palleschi MT, Sidor D, Bednarski D, Burns J, Frattaroli M. Bariatric surgery: patient incision care and discharge concerns. Ostomy Wound Manage 2006; 52: 48-52.

30. Pieper B, Sieggreen M, Nordstrom CK, Freeland B, Kulwicki P, Frattaroli M, Sidor D, Palleschi MT, Burns J, Bednarski D. Discharge knowledge and concerns of patients going home with a wound. J Wound Ostomy Continence Nurs 2007; 34: 245-53.

31. Subeh MM, Salami I, Saleh MYN. Most frequent and severe symptoms and learning needs among CABG patients. Int J Nursing 2014; 1: 167-82. 